\title{
Sustainability Reporting and Corporate Attributes: An Emerging Market Perspective
}

\author{
AHMET ÖZCAN
}

\begin{abstract}
Sustainability reporting is one of the latest trends that shape corporate reporting practices in the current business climate. With the advent of globalization, firms have begun to report environmental, ethical, social responsibility and human resource policies. Non-financial information that can enhance the quality of investment decisions is disclosed in sustainability reports. This paper aims to analyze the association between sustainability reporting and corporate attributes using a sample that includes 106 firms operating in Turkey. Using pooled cross-sectional logistic regression analysis, the empirical findings reveal that firm size, profitability, leverage, board independency and industry membership are important corporate attributes affecting the decision to issue sustainability report. The empirical findings of this paper are expected to provide valuable insights regarding sustainability reporting practices for stakeholders.
\end{abstract}

Keywords: Corporate sustainability; sustainability reporting; corporate reporting

\section{INTRODUCTION}

In the modern business environment, firms are required to report financial statements such as balance sheet, cash flow statement and profit and loss statement. Corporate reporting is rapidly evolving to meet changing needs of financial statement users. There is an increasing awareness of impacts of firms on the environment and society (Rinaldi et al. 2018). Socially responsible investing has become crucial component of global financial markets for the last half century (Rockness \& Williams 1988). Stakeholders such as investors, creditors and stockholders demand more transparency on environmental and social issues from firms. Sustainability reporting enables firms to disclose these matters to the public.

The environment is not infinite suppliers of physical resources and has no limitless capacity to absorb all industrial waste. Firms should focus on to develop technologies that can make the natural resources last longer. Sustainability reporting is an example of voluntary reporting practice that enables insider and external stakeholders to monitor social and environmental performance of the firm (Christofi et al. 2012; Zwetsloot \& Marrewijk 2004). Sustainability reporting practices appear to gain prominent momentum in the near future. As a developing area, the underlying concepts and boundaries of sustainability reporting are rapidly evolving due to changing expectations of investors, creditors and shareholders. Firms have high flexibility in the preparation of sustainability reporting. However, sustainability reporting is expected to disclose, in detail, the impacts of firms' operations on environmental, social and economic issues.

Sustainability reporting has become a topic of research interest for practitioners and academicians for several decades. Many research papers have analyzed the practical and theoretical implications of sustainability reporting. Sustainability reporting practices have been adopted by firms operating in the developed economies. On the other hand, in developing economies, sustainability reporting is in the infancy stage. Firms operating in developing economies should take further steps to enhance sustainability reporting practices.

Historically, sustainability reporting has been adopted by private firms not by public sector firms (Williams et al. 2011). Investors, creditors and stockholders are increasingly considering sustainability as a prominent factor that influences firms' success (Searcy \& Elkhawas 2012). Sustainability reporting provides various types of benefits for internal and external stakeholders of the firm, for instance, it improves transparency (Oliveira et al. 2010), positively influences corporate reputation (Glass 2012; Simnett et al. 2009) and facilitates long-term capital flows. Although these benefits, firms operating in developing economies are not willing to adopt sustainability reporting. This may be because sustainability reporting brings new responsibilities and challenges for these firms.

In the present study, Turkey is selected for several reasons. The vast majority of the present literature are based on Western countries, especially USA and UK. There is few papers (Bhatia \& Tuli 2017; Lourenço \& Branco 2013; Alsaeed 2006) that aim to examine factors affecting disclosure of sustainability reporting in an emerging country context. The present study enables to make a comparison between determinants of sustainability report disclosure in a developing country and developed country. Turkey is a developing country located in Europe and Asia and financial reporting practices in Turkey are mainly influenced by International Accounting Standards Board (IASB). Turkish financial markets have grabbed significant attention from institutional investors around the world for the last two decades. Block holder ownership is highly common among firms in Turkey, similar to other emerging countries. With the advent of liberalization policies in 1980s, corporate reporting practices have rapidly evolved. Turkish regulatory authorities have taken important measures that make 
corporate reporting practices more stakeholder-oriented. The interest of the Turkish case is also associated with increasing awareness of sustainability issues in Turkey. As shown in Table I, the number of Turkish firms issuing sustainability reports has increased over the last six years.

TABLE 1 . Sustainability reports by year

\begin{tabular}{cc}
\hline Year & The number of Turkish firms issuing sustainability report \\
\hline 2014 & 15 \\
2015 & 29 \\
2016 & 43 \\
2017 & 48 \\
2018 & 54 \\
2019 & 61 \\
\hline
\end{tabular}

Sustainability reports can be used by Turkish firms as a prominent tool that instigates communication with external stakeholders, thus mitigating agency conflicts. Also, the disclosure of sustainability reports enables firm management to preempt regulatory sanctions and compliance costs (Lim et al., 2007).

The objective of this paper is to analyze how corporate attributes influence sustainability reporting by utilizing a sample of firms operating in Turkey. The rest of the paper is structured as follows; second section presents prior studies and research hypotheses. Third section expatiates research design. Fourth section argues the empirical results. In the last section, the concluding remarks and recommendation for future studies are provided, along with limitations of the study.

\section{LITERATURE REVIEW AND HYPOTHESIS DEVELOPMENT}

This section is devoted to the literature review and hypothesis development. The theoretical framework used in the present study combines agency theory and legitimacy theory. Agency theory and legitimacy theory are used to develop a theoretical basis for identifying corporate attributes that influence sustainability reporting disclosure. The number of studies that aim to analyze determinants of sustainability reporting disclosure has increased in the last decade. Previous studies demonstrated that sustainability reporting is a common practice in countries where education level, stakeholder awareness and economic welfare are relatively high.

The conflict of interest that may occur between stockholders and firm management leads agency costs (Eisenhardt 1989). The management of firms tries to implement policies that boost the effectiveness of internal monitoring mechanisms and improve the quality of voluntary disclosures so as to reduce agency costs (Shamil et al. 2014). Although agency theory is the most important theory in explaining determinants of sustainability disclosures, legitimacy theory has also been used to identify incentives that drive firms to disseminate sustainability reports. The legitimacy of a firm is weakened when the whole society deems that a firm fails to responsibly conduct its operations. According to legitimacy theory, firms adopt sustainability reporting to enhance the public perception of their operations (Deegan 2002).

Size is one of the key factors affecting corporate reporting process. Large-sized firms grab too much attention from policymakers, standard setting bodies, investors, creditors and media. Thus, large-sized firms are under heavy pressure to satisfy informational needs of the society (Dienes et al. 2016). Small-sized firms have scarce resources, thus, they are likely fail to allocate necessary resources for the preparation of sustainability reports. Bhatia and Tuli (2017), Meek et al. (1995), Branco et al. (2014) and Shamil et al. (2014) assert that firm size positively influences sustainability reporting. The possibility of agency conflicts between management and external stakeholders is significantly high in large firms. The management of large-sized firms attempts to increase sustainability disclosures to mitigate agency conflicts and gain legitimacy. This discussion leads to the following hypothesis.

\section{$\mathrm{H}_{1}$ : Large-sized firms are more likely to issue sustainability reports.}

Firms that achieve high profitability are more inclined to disclose sustainability reporting compared to firms that have low profitability. There are several reasons why profitable firms give importance to sustainability reporting. Firms have a strong desire to disclose good news to have advantages of reporting it (Mahajan \& Chander 2007). The high level of profit urges firm management to provide more information to raise share price (Oliveira et al. 2006). Also, profitable firms can cover the cost of voluntary disclosures. Previous studies (Branco et al. 2014; Iyer \& Lulseged 2013; Lim et al. 2007) found that as profitability increases, firms are more likely to issue sustainability reports. Based on this discussion, the following hypothesis is formulated:

$\mathrm{H}_{2}$ : High-profitability firms are more likely to issue sustainability reports. 
The use of leverage affects firms in many ways. Firms with high leverage attract close scrutiny from creditors. Debt covenants enable creditors to monitor and control the actions of the firm management. By disclosing more information, a firm management signals to creditors that the firm has ability to repay its debts (Guidara et al. 2014). According to agency theory, highly-leveraged firms are expected to voluntarily disclose more information to ease pressure from their creditors. Hummel and Schlick (2016) and Roberts (1992) claimed that there is a positive relationship between financial leverage and sustainability reporting. Based on this discussion, it is hypothesized that:

$\mathrm{H}_{3}$ : $\quad$ Firms with high leverage are more likely to issue sustainability reports.

The presence of outside board members protects the interests of stockholders acting as a non-dependent mediator. Fama and Jensen (1983) stated that outside board members play a critical role in mitigating agency problems. Herda et al. (2012) and Lim et al. (2007) stated that outside board members increase the effectiveness of corporate governance mechanisms, monitoring actions of the firm management. Shamil et al. (2014) asserted that the board dominated by outside board members puts pressure on firm management to mitigate agency problems by disclosing more information. The findings of prior studies on the relationship between board independence and sustainability reporting are contradictory. Boessa and Kumar (2007), Xiang (2009) and Faisal et al. (2012) found that board independence has no significant effect on the level of voluntary information disclosure. On the other hand, Chau and Gray (2010) and Barako and Brown (2008) reported that board independence positively influences the level of voluntary information disclosure. Based on this discussion, the following hypothesis is formulated:

$\mathrm{H}_{4}$ : $\quad$ Firms having a higher proportion of outside board members are more likely to issue sustainability reports.

The nature of industry in which a firm operates influences firms' sustainability reporting practices. The level of voluntary information disclosure varies between industries (Lim et al. 2007). Firms operating in mining, chemical, oil and gas industry have considerable impacts on the environment and grab more attention from the society. Firms operating in such industries have much more tendency to disclose sustainability reports to respond pressures of their stakeholders and legitimize their operations. Bhatia and Tuli (2017), Iyer and Lulseged (2013) and Jennifer and Taylor (2007) documented that the nature of industry significantly affects firms' sustainability disclosure. In order to analyze the association between the nature of industry and sustainability reporting, the following hypothesis is developed:

$\mathrm{H}_{5}$ : $\quad$ Firms operating in mining, chemical, oil and gas industry are more likely to issue sustainability reports.

Roberts (1992) stated that ownership structure has vital impacts on firms' disclosure policy. It is generally assumed that the shareholders of widely held firms have no direct access to information sources, hence, agency costs are high in widely held firms (Fama \& Jensen 1983). Sustainability reporting could provide valuable benefits to widely held firms, serving as a mechanism that decreases agency costs arising from information asymmetry. Prencipe (2004) posited that widely held firms are expected to provide more voluntary information than narrowly held firms to diminish information asymmetries between internal and external stakeholders. Traditionally, family businesses dominate Turkish business environment. Thus, the ownership concentration in Turkish firms is significantly high. As the financial markets in Turkey develop, dispersed ownership can be observed. Firms with high ownership concentration are likely to refrain from voluntarily disclosure of information (Brammer and Pavelin, 2008). As a consequence, ownership dispersion is expected to be positively related with sustainability reporting. The following hypothesis is developed:

$\mathrm{H}_{6}$ : Widely held firms are more likely to issue sustainability reports.

\section{SAMPLE AND DATA}

The sample employed in the empirical analysis consists of 53 Turkish firms that publish sustainability reports and 53 Turkish firms that did not publish sustainability reports. The time period analyzed in the study is 2014-2018. This time period was chosen since few firms reported the necessary information for the prior years. The financial statements, sustainability and annual reports of sample firms are retrieved from their websites. Turkish firms disclose sustainability reports on annual basis. Table II presents the industry classifications of sample firms. The data indicates that the sample includes firms from five different industries: consumer goods industry (43.3\%), financials $(24.5 \%)$, technology and telecommunications (13.2\%), oil, gas and energy (13.2\%), chemical (5.7\%). It is worth mentioning that sample firms are matched on the basis of industry. 
TABLE 2. Sample by industry

\begin{tabular}{ccc}
\hline Industry & Frequency & Percentage \\
\hline Consumer goods & 46 & 43.3 \\
Financials & 26 & 24.5 \\
Technology and telecommunications & 14 & 13.2 \\
Oil, gas and energy & 14 & 13.2 \\
Chemical & 6 & 5.7 \\
Total & 106 & 100 \\
\hline
\end{tabular}

\section{EMPIRICAL MODEL}

Based on Bhatia and Tuli (2017), Nazari et al. (2015) and Iyer and Lulseged (2013), six predictor variables are used in the research model. Following Branco et al. (2014), Kend (2015) and Kolk and Perego (2010), a pooled cross-sectional logistic regression model is used to test the research hypotheses. The following empirical model is estimated.

$S R_{i}=\beta_{0}+\beta_{1} S I Z E_{i}+\beta_{2} P R O F_{i}+\beta_{3} L E V_{i}+\beta_{4} B I N D_{i}+\beta_{5} I N D_{i}+\beta_{6} O W N_{i}+\varepsilon_{i}$

in which for firm i;

SR: Sustainability reporting is a dummy variable that takes 1 if the sample firm discloses the sustainability reporting and zero if otherwise.

SIZE: Firm size is the natural logarithm of total assets.

PROF: Profitability is the ratio of net income to total assets.

LEV: Leverage is the ratio of total debt to total stockholders' equity.

BIND: Board independency is the percentage of outside board members.

IND: Industry is a dummy variable that takes 1 if the firm operates in mining, chemical, oil and gas industry and zero if otherwise.

OWN: Ownership concentration is the percentage of shares owned by the largest shareholder.

$\varepsilon$ : error term.

\section{DESCRIPTIVE STATISTICS}

Table III presents descriptive statistics for test variables. SIZE exhibited a large range of variation, having a mean of 8.650 with a minimum value of 5.695 to a maximum of 11.6 . The mean of profitability (PROF) is 0.09 , the highest being 0.201 and the lowest -0.11 . The leverage ratio ranges from 0.368 to 0.662 , with a mean value of 0.571 . Regarding leverage, it appears that some sample firms rely more on debt financing than equity financing. The mean of board independency (BIND) is $24.9 \%$, indicating that the proportion of outside board members represents only 24.9 percent of boards of sample firms. The ownership concentration (OWN) for the sample firms, on average, 0.447 with a range of 0.17 and 0.85 .

TABLE 3. Descriptive statistics for the dependent and independent variables

\begin{tabular}{cccccc}
\hline Variable & $\mathrm{n}$ & Mean & SD & Min & Max \\
\hline SR & 374 & 0.500 & 0.500 & 0 & 1 \\
SIZE & 374 & 8.560 & 1.504 & 5.695 & 11.6 \\
PROF & 374 & 0.090 & 0.063 & -0.11 & 0.201 \\
LEV & 374 & 0.571 & 0.093 & 0.368 & 0.662 \\
BIND & 374 & 0.249 & 0.092 & 0 & 0.44 \\
IND & 374 & 0.437 & 0.497 & 0 & 1 \\
OWN & 374 & 0.447 & 0.176 & 0.17 & 0.85 \\
\hline
\end{tabular}

Notes: SR is a dummy variable that takes 1 if the sample firm discloses the sustainability reporting and zero if otherwise; SIZE is equal to the natural logarithm of total assets; PROF is equal to the ratio of net income to total assets; LEV is equal to the ratio of total debt to total stockholders' equity; BIND is equal to the percentage of outside board members; IND is a dummy variable that takes 1 if the firm operates in mining, chemical, oil and gas industry and zero if otherwise; OWN is equal to the percentage of shares owned by the largest shareholder. 
Pearson correlation coefficients are reported in Table IV. It can be seen that there is no absolute value of correlation coefficient above 0.64 , implying that multicollinearity problem is not a serious concern in the regression analysis (Gujarati 2003). The results indicated that sustainability reporting (SR) has low positive and statistically significant relations with profitability $(\mathrm{r}=0.187, \mathrm{p}<0.01)$ as well as with board independency $(\mathrm{r}=0.232, \mathrm{p}<0.01)$, however it has moderate, negative and statistically significant relation with leverage $(\mathrm{r}=-0.639, \mathrm{p}<0.01)$. Additionally, the statistically insignificant relationship is found between ownership concentration and sustainability reporting.

TABLE 4. Pearson correlation coefficients

\begin{tabular}{|c|c|c|c|c|c|c|c|}
\hline Variable & SR & SIZE & PROF & LEV & BIND & IND & OWN \\
\hline SR & 1 & & & & & & \\
\hline SIZE & $0.266^{* * *}$ & 1 & & & & & \\
\hline PROF & $0.187^{* * *}$ & $0.104^{* *}$ & 1 & & & & \\
\hline LEV & $-0.639 * * *$ & $-0.164 * * *$ & $-0.114^{* *}$ & 1 & & & \\
\hline BIND & $0.232 * * *$ & $0.145^{* * *}$ & $0.237 * * *$ & $-0.155^{* * *}$ & 1 & & \\
\hline IND & $0.281 * * *$ & 0.051 & 0.100 & $-0.266^{* * *}$ & $0.255^{*}$ & 1 & \\
\hline OWN & -0.018 & $-0.252 * * *$ & $0.283 * * *$ & 0.034 & $0.140^{* * *}$ & -0.011 & 1 \\
\hline
\end{tabular}

Notes: SR is a dummy variable that takes 1 if the sample firm discloses the sustainability reporting and zero if otherwise; SIZE is equal to the natural logarithm of total assets; PROF is equal to the ratio of net income to total assets; LEV is equal to the ratio of total debt to total stockholders' equity; BIND is equal to the percentage of outside board members; IND is a dummy variable that takes 1 if the firm operates in mining, chemical, oil and gas industry and zero if otherwise; OWN is equal to the percentage of shares owned by the largest shareholder. $* *$ Significant at a 0.05 level, $* * *$ Significant at a level 0.01 level.

\section{REGRESSION RESULTS}

The results of logistic regression analysis are reported in Table V. Coefficients on predictor variables are estimated through the logit model, using sustainability reporting (SR) as a dependent variable. With a $\chi^{2}$ of 221.40 , which is significant at 1 percent, the logit model has considerable explanatory power. Hosmer and Lemeshow test is run to analyze the robustness of logit model. The result is not statistically significant $(p<0.945)$, it can be stated that the logit model fits well. The pseudo Rsquare is 0.427 , namely $42.7 \%$ percent of variations in the issuance of sustainability reports can be explained by predictor variables. The overall predictive accuracy of the logit model is $78.2 \%$.

Table $\mathrm{V}$ indicates that firm size (SIZE) has a positive and significant impact on sustainability reporting $(\beta=0.416$, $\mathrm{p}<0.01$ ). This finding is consistent with those of Bhatia and Tuli (2017), Meek et al. (2009), Branco et al. (2014) and Shamil et al. (2014). Large-sized firms are more visible in the business environment, grabbing more attention from the public. Thus, large-sized firms are more inclined to issue sustainability reports so as to ease pressure from their stakeholders. Another reasonable explanation for this finding might be that large-sized firms have abundant resources for broader disclosure. The hypothesis 1 that large-sized firms are more likely to issue sustainability reports is supported.

The coefficient on profitability (PROF) is positive and statistically significant at the 0.10 level. This finding corroborated Iyer and Lulseged (2013) and Lim et al. (2007) who found that profitability positively influences the likelihood of issuing sustainability report. One possible explanation for this finding is that the management of profitable firms tends to issue sustainability reports in order to make the firm's profit figures better known to the public. The hypothesis 2 that highprofitability firms are more likely to issue sustainability reports is supported.

The coefficient for leverage (LEV) is -20.626. It is statistically significant at the 0.01 level which suggests that lowleveraged firms are more likely to disclose sustainability reports than highly-leveraged firms. This result appears to support the findings of Andrikopoulos and Kriklani (2013) who stated that high financial leverage mitigates the extent of the voluntary disclosure. A plausible explanation for this finding is that highly-leveraged firms are much more prone to agency conflicts, hence these firms are more likely to disclose voluntary information to minimize agency conflicts. The hypothesis 3 that firms with high leverage are more likely to issue sustainability reports is not supported.

Positive association was found between board independency (BIND) and sustainability reporting ( $\beta=2.981$, $\mathrm{p}<0.10)$. This could be due to the fact that independent board members exert pressure on firm management to disclose more voluntary information to the external stakeholders for alleviating agency costs. This result agrees with Herda et al. (2012), Kent and Monem (2008) and Barako and Brown (2008) who asserted that the appointment of outside board members positively influences sustainability reporting. It is worth noting that presently in Turkey, at least one-third of publicly held firms' board should have independent directors. The hypothesis 4 that firms having a higher proportion of outside board members are more likely to issue sustainability reports is supported.

The results of logit analysis reveal that industry (IND) is found to be a statistically significant predictor of sustainability reporting disclosure $(\beta=0.762, p<0.05)$. Studies by Iyer and Lulseged (2013), Deegan and Gordon (1996) and 
Branco et al. (2014) have found similar evidence that industry type is one of the factors affecting firms' decision to issue sustainability reports. This finding, from the perspective of legitimacy theory, confirms that firms operating in high-risk industries tend to issue sustainability reports to enhance their legitimacy in the society. Hypothesis 5 that firms operating in mining, chemical, oil and gas industry are more likely to issue sustainability reports is supported.

Finally, the regression result for ownership concentration $(\mathrm{OWN})$ is statistically insignificant $(\beta=0.404, \mathrm{p}<0.05)$. This result supports the findings of Naser et al. (2002), Alsaeed (2006) and Wallace et al. (1994) who stated that ownership concentration does not affect the sustainability reporting disclosure. Hypothesis 6 that widely held firms are more likely to issue sustainability reports is not supported.

TABLE 5. Results of logistic regression analysis

\begin{tabular}{ccc}
\hline Variable & Coefficient & Z value \\
\hline SIZE & 0.416 & $3.80^{* * *}$ \\
PROF & 4.556 & $1.80^{*}$ \\
LEV & -20.626 & $-9.47^{* * *}$ \\
BIND & 2.981 & $1.74^{*}$ \\
IND & 0.762 & $2.47^{* *}$ \\
OWN & 0.404 & 0.43 \\
Constant & 6.821 & 4.45 \\
N & 374 & \\
LR chi2(6) & 221.4 & \\
Prob > chi2 & 0.000 & \\
Hosmer and Lemeshow & 0.945 & 0.427 \\
Pseudo R & $78.2 \%$ & \\
Predictive accuracy & & \\
\hline
\end{tabular}

Notes: SIZE is equal to the natural logarithm of total assets; PROF is equal to the ratio of net income to total assets; LEV is equal to the ratio of total debt to total stockholders' equity; BIND is equal to the percentage of outside board members; IND is a dummy variable that takes 1 if the firm operates in mining, chemical, oil and gas industry and zero if otherwise; OWN is equal to the percentage of shares owned by the largest shareholder.

***Significant at a level 0.01 level, **Significant at a 0.05 level, *Significant at a level 0.1 level.

From the results of logistic regression analysis, it is clear that agency theory and legitimacy theory appear to be useful in explaining the behavior of firms listed on Borsa Istanbul for the disclosure of sustainability reporting. The results of empirical analysis support all research hypotheses except hypothesis 6 , hence contribute to the existing literature by establishing a model that identifies factors affecting the decision of firms listed on Borsa Istanbul to disclose sustainability reporting. Turkish firms can get benefit from the value creation role of sustainability reporting. The disclosure of sustainability reports can attract individual and institutional investors who pay considerable attention to the sustainability issues.

\section{CONCLUDING REMARKS}

This paper investigated the determinants of sustainability reporting in Turkey. A sample of 106 firms listed on Borsa Istanbul was chosen for the present study. The results of empirical analysis indicated that size, profitability, board independency and industry membership have a positive and statistically significant coefficient, whereas leverage has a negative and statistically significant coefficient. Additionally, ownership concentration is not found to be a statistically significant contributor to the empirical model.

Empirical findings reveal that large-sized firms, profitable firms, low-leveraged firms, firms with a board having a relatively large number of outside board members and firms operating in mining, chemical, oil and gas industry are more likely to issue sustainability reports. Five out of six hypotheses are accepted. Agency and legitimacy theory are useful in explaining empirical findings of this study. According to the results of empirical analysis, sustainability reporting appears to be used by sample firms to legitimize their operations and mitigate agency costs. Stakeholders such as creditors, suppliers, shareholders and customers should be not only concerned about firms' financial performance and position, but also the effects of their operations on the environment and society.

In the current business environment, sustainability reporting sheds light on how firms deal with effects of their operations on society and environment. It is believed that the use of sustainability reports along with financial statements may increase the quality of investment decisions. The development of sustainability reporting is not at the desired level in Turkey. The sustainability reporting practices by Turkish firms are in the infancy stage. Although there are 487 firms listed on Borsa Istanbul, only 56 of them issue sustainability reports in 2019. The low disclosure of sustainability reports is 
associated with the fact that sustainability reporting is voluntary in Turkey. Regulatory agencies should set out a clear legal framework that encourages Turkish firms to issue sustainability reports.

This paper is subject to some limitations; thus, empirical findings should be evaluated in this context. First of all, other factors such as CEO duality, board size and institutional ownership may influence sustainability reporting. These factors are not incorporated into the empirical model. Hence, a further study can examine the effect of these corporate governance variables on the disclosure of sustainability reporting. Secondly, only $11.1 \%$ of firms listed on Borsa Istanbul disclosed sustainability report. This low rate may distort the validity of the empirical findings. Given that this study is based on the Turkish institutional setting, the findings of empirical analysis cannot be generalized to other emerging and developed countries. The empirical findings of this study, I believe, can enable regulatory agencies to effectively set out principles and guidelines for sustainability disclosures. Since the economy of each country has its own unique dynamics, future studies can use cross-country data to investigate determinants of sustainability reporting. Future studies could employ advanced statistical methods to comprehensively analyze corporate attributes affecting the quality of sustainability reporting.

\section{REFERENCES}

Alsaeed, K. 2006. The association between firm-specific characteristics and disclosure: The case of Saudi Arabia. Managerial Auditing Journal 21(5): 476-496.

Andrikopoulos, A. \& Kriklani, N. 2013. Environmental disclosure and financial characteristics of the firm: The case of Denmark. Corporate Social Responsibility and Environmental Management 20(1): 55-64.

Barako, D.G. \& Brown, A. M. 2008. Corporate social reporting and board representation: Evidence from the Kenyan banking sector. Journal of Management \& Governance 12(4): 309.

Bhatia, A. \& Tuli, S. 2017. Corporate attributes affecting sustainability reporting: An Indian perspective. International Journal of Law and Management 59(3): 322-340.

Boesso, G. \& Kumar, K. 2007. Drivers of corporate voluntary disclosure: A framework and empirical evidence from Italy and the United States. Accounting, Auditing \& Accountability Journal 20(2): 269-296.

Brammer, S., \& Pavelin, S. 2008. Factors influencing the quality of corporate environmental disclosure. Business Strategy and the Environment 17(2): 120-136.

Branco Castelo, M., Delgado, C., Ferreira Gomes, S. \& Cristina Pereira Eugénio, T. 2014. Factors influencing the assurance of sustainability reports in the context of the economic crisis in Portugal. Managerial Auditing Journal 29(3): 237252 .

Chau, G. \& Gray, S. J. 2010. Family ownership, board independence and voluntary disclosure: Evidence from Hong Kong. Journal of International Accounting, Auditing and Taxation 19(2): 93-109.

Christofi, A., Christofi, P. \& Sisaye, S. 2012. Corporate sustainability: historical development and reporting practices. Management Research Review 35(2): 157-172.

Deegan, C. \& Gordon, B. 1996. A study of the environmental disclosure practices of Australian corporations. Accounting and Business Research 26(3): 187-199.

Deegan, C. 2002. Introduction: The legitimising effect of social and environmental disclosures-A theoretical foundation. Accounting, Auditing \& Accountability Journal 15(3): 282-311.

Dienes, D., Sassen, R. \& Fischer, J. 2016. What are the drivers of sustainability reporting? A systematic review. Sustainability Accounting, Management and Policy Journal 7(2): 154-189.

Eisenhardt, K.M. 1989. Agency theory: An assessment and review. Academy of Management Review 14(1): 57-74.

Faisal, F., Tower, G. \& Rusmin, R. 2012. Legitimising corporate sustainability reporting throughout the world. Australasian Accounting, Business and Finance Journal 6(2): 19-34.

Fama, E.F. \& Jensen, M.C. 1983. Separation of ownership and control. The Journal of Law and Economics 26(2): 301-325.

Glass, J. 2012. The state of sustainability reporting in the construction sector. Smart and Sustainable Built Environment 1(1): $87-104$.

Guidara, A., Khlif, H. \& Jarboui, A. 2014. Voluntary and timely disclosure and the cost of debt: South African evidence. Meditari Accountancy Research 22(2): 149-164.

Gujarati, D. N. 2003. Basic Econometrics. Fourth Edition. Singapura: McGraw-Hill.

Herda, D.N., Taylor, M.E. \& Winterbotham, G. 2012. The effect of board independence on the sustainability reporting practices of large US firms. Issues in Social \& Environmental Accounting 6(3/4): 25-44.

Hummel, K. \& Schlick, C. 2016. The relationship between sustainability performance and sustainability disclosureReconciling voluntary disclosure theory and legitimacy theory. Journal of Accounting and Public Policy 35(5): 455476.

Iyer, V. \& Lulseged, A. 2013. Does family status impact US firms' sustainability reporting? Sustainability Accounting, Management and Policy Journal 4(2): 163-189.

Jennifer Ho, L. C., \& Taylor, M. E. 2007. An empirical analysis of triple bottom-line reporting and its determinants: Evidence from the United States and Japan. Journal of International Financial Management \& Accounting 18(2): 123-150. 
Kend, M. 2015. Governance, firm-level characteristics and their impact on the client's voluntary sustainability disclosures and assurance decisions. Sustainability Accounting, Management and Policy Journal 6(1): 54-78.

Kent, P. \& Monem, R. 2008. What drives TBL reporting: good governance or threat to legitimacy?. Australian Accounting Review 18(4): 297-309.

Kolk, A. \& Perego, P. 2010. Determinants of the adoption of sustainability assurance statements: An international investigation. Business Strategy and the Environment 19(3): 182-198.

Lim, S., Matolcsy, Z. \& Chow, D. 2007. The association between board composition and different types of voluntary disclosure. European Accounting Review 16(3): 555-583.

Lourenço, I.C. \& Branco, M.C. 2013. Determinants of corporate sustainability performance in emerging markets: The Brazilian case. Journal of Cleaner Production 57: 134-141.

Mahajan, P. \& Chander, S. 2007. Corporate disclosure practices in Indian software industry: An empirical study. The IUP Journal of Accounting Research and Audit Practices 6(2): 43-70.

Meek, G.K., Roberts, C.B. \& Gray, S.J. 1995. Factors influencing voluntary annual report disclosures by US, UK and continental European multinational corporations. Journal of International Business Studies 26(3): 555-572.

Naser, K., Al-Khatib, K. \& Karbhari, Y. 2002. Empirical evidence on the depth of corporate information disclosure in developing countries: The case of Jordan. International Journal of Commerce and Management 12(3/4): 122-155.

Nazari, J.A., Herremans, I.M. \& Warsame, H.A. 2015. Sustainability reporting: External motivators and internal facilitators. Corporate Governance 15(3): 375-390.

Oliveira, L., Lima Rodrigues, L. \& Craig, R. 2006. Firm-specific determinants of intangibles reporting: Evidence from the Portuguese stock market. Journal of Human Resource Costing \& Accounting 10(1):11-33.

Oliveira, L., Lima Rodrigues, L. \& Craig, R. 2010. Intellectual capital reporting in sustainability reports. Journal of Intellectual Capital 11(4): 575-594.

Prencipe, A. 2004. Proprietary costs and determinants of voluntary segment disclosure: Evidence from Italian listed companies. European Accounting Review 13(2): 319-340.

Rinaldi, L., Unerman, J. \& De Villiers, C. 2018. Evaluating the integrated reporting journey: Insights, gaps and agendas for future research. Accounting, Auditing \& Accountability Journal 31(5): 1294-1318.

Roberts, R.W. 1992. Determinants of corporate social responsibility disclosure: An application of stakeholder theory. Accounting, Organizations and Society 17(6): 595-612.

Rockness, J. \& Williams, P.F. 1988. A descriptive study of social responsibility mutual funds. Accounting, Organizations and Society 13(4): 397-411.

Searcy, C. \& Elkhawas, D. 2012. Corporate sustainability ratings: An investigation into how corporations use the Dow Jones Sustainability Index. Journal of Cleaner Production 35: 79-92.

Shamil, M., M. Shaikh, J., Ho, P.L. \& Krishnan, A. 2014. The influence of board characteristics on sustainability reporting: Empirical evidence from Sri Lankan firms. Asian Review of Accounting 22(2): 78-97.

Simnett, R., Vanstraelen, A. \& Chua, W. F. 2009. Assurance on sustainability reports: An international comparison. The Accounting Review 84(3): 937-967.

Wallace, R.O., Naser, K. \& Mora, A. 1994. The relationship between the comprehensiveness of corporate annual reports and firm characteristics in Spain. Accounting and Business Research 25(97): 41-53.

Williams, B., Wilmshurst, T. \& Clift, R. 2011. Sustainability reporting by local government in Australia: Current and future prospects. Accounting Forum 35(3): 176-186.

Xiang, X.I.A.O. 2009. Effects of corporate governance structure and company characteristics on social responsibility information disclosure. In Proceeding of 2009 International Conference on Management Science and Engineering, Beijing Jiaotong University.

Zwetsloot, G.I.M. \& Van Marrewijk, M.N. 2004. From quality to sustainability. Journal of Business Ethics 55(2): 79-82.

\author{
Ahmet Özcan \\ Faculty of Business \\ Adana Alparslan Türkeş Science and Technology University \\ 01250 Balcalı Mahallesi \\ Çatalan Caddesi No: 201/1 \\ Sarıçam/Adana \\ TURKEY \\ E-mail: aozcan@atu.edu.tr
}

